\title{
Health of the LGBTI+ Population in Primary Health Care and the Insertion of Nursing
}

\author{
Saúde da população LGBTI+ na Atenção Primária à Saúde e a inserção da Enfermagem
} Salud de la población LGBTI+ en la Atención Primaria de la Salud e inserción de la Enfermería

Juliana Spinula dos Santos ${ }^{1}($ (D)

Rodrigo Nogueira da Silva ${ }^{1}($ C) Márcia de Assunção Ferreira ${ }^{1}$ (D)

1. Universidade Federal do Rio de Janeiro, Escola de Enfermagem Anna Nery. Rio de Janeiro, RJ, Brasil.
Corresponding author:

Márcia de Assunção Ferreira.

E-mail: marcia.eean@gmail.com

Submitted on 05/30/2019.

Accepted on 07/30/2019.

DOI: 10.1590/2177-9465-EAN-2019-0162

\section{Abstract}

Objective: To reflect on the approaches to the health of the LGBTI+ population, Primary Health Care and Nursing in the care of this population. Method: The reflection is based on a brief characterization of the LGBTI+ population and their health, an analysis of the nurses' work in Primary Health Care (PHC), and a debate about particularities of the nursing care for the LGBTI+ population in the PHC. Results: The LGBTI+ population is composed of many populations defined by the diversity of gender identity and expression, sexual orientation, and biological sex. In Family Health teams, nurses must know the main demands of this population. The institutional reorientation of PHC imposes new challenges to the enjoyment of the right to health of the LGBTI+ population. Conclusion and implications for practice: Although the National LGBT Health Policy is seven years old, studies are stil scarce, foremost in Nursing. Considering that the LGBTI+ population is also under the Nursing responsibility in the PHC, it is up to this professional category to provide integral assistance with a view to minimizing the inequalities suffered by this population.

Keywords: Sexual and Gender Minorities; Primary Care Nursing; Primary Health Care.

\section{Resumo}

Objetivo: Refletir sobre as abordagens da saúde da população LGBTI+, a Atenção Primária à Saúde e a Enfermagem no cuidado a esta população. Método: A reflexão se baseia em uma breve caracterização da população LGBTI+ e sua saúde, uma análise da atuação da enfermeira na Atenção Primária à Saúde (APS) e um debate sobre particularidades do cuidado de enfermagem à população LGBTI+ na APS. Resultados: A população LGBTI+ é composta por populações que se definem pela diversidade de identidade e de expressão de gênero, orientação sexual e sexo biológico. Nas equipes de Saúde da Família, as enfermeiras devem conhecer as principais demandas dessa população. A reorientação institucional da APS impõe novos desafios à efetivação do direito à saúde da população LGBTI+. Conclusão e implicações para a prática: Embora a Política Nacional de Saúde LGBT tenha sete anos, estudos ainda são escassos, sobretudo na Enfermagem. Considerando que a população LGBTI+ está, também, sob a responsabilidade da Enfermagem no âmbito da APS, cabe a esta categoria profissional prestar assistência integral com vistas à minimização das desigualdades sofridas por esta população.

Palavras-chave: Minorias Sexuais e de Gênero; Enfermagem de Atenção Primária; Atenção Primária à Saúde.

\section{REsumen}

Objetivo: Reflexionar sobre los enfoques en la salud de la población LGBTI +, la Atención Primaria de la Salud y la Enfermería en el cuidado de esta población. Método: La reflexión se basa en una breve caracterización de la población LGBTI+ y su salud, en un análisis del trabajo de las enfermeras en la Atención Primaria de la Salud (APS) y en un debate sobre las particularidades y la atención de la enfermería para la población LGBTI+ en la APS. Resultados: La población LGBTI+ está compuesta por muchas poblaciones definidas por la diversidad de identidad y expresión de género, orientación sexual y sexo biológico. En los equipos de Salud de la Familia, las enfermeras deben conocer las principales demandas de esta población. La reorientación instituciona de la APS impone nuevos desafíos para realizar el derecho a la salud de la población LGBTI+. Conclusión e implicaciones para la práctica: Aunque la Política Nacional de la Salud LGBT tenga siete años, los estudios aún son escasos, especialmente en enfermería. Teniendo en cuenta que la población LGBTI+ también está bajo la responsabilidad de la Enfermería en el marco de la APS, corresponde a esta categoría profesional brindar asistencia integral, con el fin de minimizar las desigualdades sufridas por esta población.

Palabras clave: Minorías Sexuales y de Género; Enfermería en Atención Primaria; Atención Primaria de la Salud. 


\section{INTRODUCTION}

Gender identity is how a person identifies with the genders, whether male or female, or other non-binary identities, and sexual orientation relates to sexual, affective and emotional attraction to similar, different, or multiple genders. It is still necessary to understand the LGBTI+ population in order to recognize the diversity of gender expression, as in the case of the cross-dresser and queer populations, and the biological sex, as in the case of the intersex population. ${ }^{1}$

Among the various acronyms available to characterize the lesbian, gay, bisexual, transgender, and intersex groups, and all other gender identities and sexual orientations, the acronym LGBTI+ will be used in this study to comprehend the multiple possibilities of existence other than cis-heteronormatives, in attention to the terms and definitions about gender and sexual diversities according to the LGBTI+ Communication Manual of the 2018 National LGBTI Alliance. ${ }^{1}$

The right to health was recognized as a human right in the Universal Declaration of Human Rights in 1948 and it influenced the constitutional charters of postwar countries. This list includes Brazil, which incorporated health as a social right in the 1988 Constitution, with guarantees of universal and free access to health for the population. Nevertheless, it is observed that there are several problems that generate social exclusion in the field of public health between the legal provision and its effective materialization. $^{2}$

Regarding gender and sexual orientation, these have been recognized as human rights by the United Nations and by the Organization of American States, triggering a series of documents that treat the protection and non-discrimination of this population group. ${ }^{3}$ Nevertheless, in the health care field, similarly to the case with the general population and after 30 years of the Brazilian Constitution being enacted, inequalities are observed in the access to this fundamental right, mainly for social minorities like the LGBTI+ population. ${ }^{4}$

Health care services must have a welcoming environment, free from prejudice, and offer full attention to the LGBTI+ population, with recognition of their specificities in providing the corresponding actions and services. ${ }^{5}$ However, the LGBTI+ population is marginalized in health care services because of the prejudice and the stigma imposed upon it which, together to the lack of knowledge on the part of the health care providers and their insensitivity to its needs, entails the provision of poor quality services. ${ }^{6}$

In Brazil, the LGBTI+ population is also among the marginalized social minorities with the least access to health care services and does not receive proper assistance in the face of the opinions and value judgments of health care practitioners, whose discrimination exists in several areas of society and also in the places of health care production. ${ }^{7}$ In a review study that analyzed productions from 2004 to 2014, non-heterosexual orientation was evidenced to be a determinant factor in the difficulties to access health care services, with recommendations to expand studies and debates on the subject matter, so that there is an appreciation of health care practitioners and of health care services for the LGBTI+ population. ${ }^{8}$

Therefore, this article aims to reflect on the health care approaches of the LGBTI+ population, on Primary Health Care, and on Nursing in the care for this population.

\section{The health of LGBTI+ population, Primary Health Care, and Nursing in the care for this population}

Discussing the particularities and health demands of the LGBTI+ population in Brazil is a big challenge. A review research done after the publication of the National LGBT Health Policy, covering the period from 2011 to 2016 concluded that the history of health care for this population has been linked to the prevention of Sexually Transmitted Infections (STIs). ${ }^{9}$ This history contributed to the institutional discrimination and prejudice by the health care practitioners and, even after the Policy, articles on the advances in health care of the LGBTI+ population are scarce. ${ }^{9}$

Knowledge of the main demands of the population should guide the practice. For instance, the high rate of violence suffered by this social group, as a result of the LGBTI phobia, should prompt the health care practitioner to investigate possible acts of violence the person may be suffering at family, school, work, or in their community. A study conducted in Italy with 1,000 individuals from the LGBTI+ group evidenced experiences of violence that indicate the need for improvements in the political initiatives to mitigate this situation. ${ }^{10}$ Yet another research showed that, when laws on anti-discrimination of minority sex groups (LGBTI+) are applied, there is a synergy with the use of routine health care, which can contribute to the protection of lesbians' and gay men's health. ${ }^{11}$

LGBTI+ people that show a gender expression and nonstereotypical behavior can go unnoticed inside the medical offices. Considering plurality and diversity, and that people do not follow a pattern, the anamnesis must be meticulous and expanded, paying attention to the possible human responses and life contexts of each person, and the entire therapy must be based on participation and on respecting the autonomy and the user's life projects by the interdisciplinary reference team and possible supporters. ${ }^{12}$

The National Integral Health Policy for Lesbian, Gays, Bisexuals, Transvestites, and Transsexuals brings to the debate the importance of knowing the social determinants of health of the individuals that result directly in their quality of life. ${ }^{5}$ However, it draws attention to the fact that the LGBTI+ population is reproducing their lives in the territories, but they are dying. $A$ review study reports that the murders of LGBTI+ people evidence the maintenance of heteronormativity, and especially the elimination of transvestites shows a social cleaning up process, indicating that the public security policies for LGBTI+ need to consider the LGBTI phobic gender and culture categories to confront such crimes. ${ }^{13}$ 
Regarding the data on the transsexual individuals in the country, there is underreporting of murders, and yet it is highlighted that Brazil occupies the first place in the ranking of deaths in this group, whose data between October $1^{\text {st }}, 2017$ and September $30^{\text {th }}, 2018$ reports 167 murders, followed by 71 deaths in Mexico, 28 in the US and 21 in Colombia in the same period. ${ }^{14}$ Some of the proposals submitted by the Grupo Gay da Bahia to fight violence against LGBTI+ individuals are sexual and gender education for the general population and the creation of public policies in the health care area. ${ }^{15}$

It is noteworthy that the life expectancy of transsexual people is 35 years, while for the general population it is generally 74.9 years. ${ }^{16}$ Besides transphobia, non-violent deaths of trans people are related to complications due to HIV infection and to those due to body modifications without medical guidance. ${ }^{16}$ Respecting the use the social name, an essential tool to diminish the discrimination of the trans population in the health care services, ${ }^{17}$ and not understanding sexual reassignment as the only outcome this population wishes, ${ }^{18}$ should also be observed. Added to this is the fact that the LGBTI+ population is more vulnerable to the use of substances, STIs, cancer, cardiovascular diseases, obesity, bullying, isolation, rejection, anxiety, depression, and suicide compared to the general population. ${ }^{6}$

Unlike cis-heterosexual people, LGBTI+ individuals need to publicly assume themselves in various moments of their lives, asserting themselves in their sexual orientations and identities, both for themselves and for their family, friends, and co-workers, in every context that they be inserted. The bisexual population is often made invisible, even by the $\mathrm{PHC}$ professionals, ${ }^{19}$ and among the specific demands of this population is the necessary diversity of prevention methods against STIs in the face of several sexual practices that this population may, even if not necessarily, adopt. ${ }^{20}$

This process of personal, family, and social acceptance can trigger a variety of mental health issues. A survey conducted in the United States with 577 individuals from the LGBTI+ group revealed that prejudice and discriminatory experiences can contribute to the rise of mental disorders. ${ }^{21}$ In Brazil, a study conducted with 19 homosexual youths evidenced that the psychological sufferings that affect them come from prejudices, heteronormative rules, stigmas, reclusions, losses, and loneliness, which several times lead them to suicidal ideation, and generates demands to the health care providers, regarding the mental health, in the face of suicide being a serious public health problem. ${ }^{22}$

The National Health Promotion Policy (NHPP) challenges us to promote health considering the social determinants of the population's health. Some of its core values are respect for diversities, including sexual orientation and gender identity, justice, and social inclusion. ${ }^{23}$

In Brazil, Primary Health Care (PHC), or Primary Care (PC), is implemented as a State policy, being the main and priority gateway to health care services, in the coordination of care and reference in the Health Care Network. The National Primary Care Policy (NPCP) was launched in 2006 and revised in 2011, with increased access, coverage and resolution, in a move towards
PHC consolidation. Nevertheless, in 2017 there was a new revision of the NPCP with important changes, whose criticisms embrace the concern with the provision of minimum care, in the conception of selective PHC; however, the expectation of some specialists is that the interests converge towards an accessible and resolute $\mathrm{PHC}$, with strengthening of the Unified Health System (Sistema Único de Saúde, SUS). ${ }^{24}$

It is noteworthy that, as a State policy and supporter of the SUS, PHC should respect its fundamental principles, considering the singularity, cultural insertion, social determinants, and conditioning factors of population's health, whose actions must converge to the protection, prevention, recovery, and promotion of health. In this sense, efforts should be made to minimize the inequalities and the exclusion of social groups, considering human diversity and the LGBTI+ population is included in this group.

The LGBTI+ population's vulnerability, the right to universal and free access to health guaranteed by the Constitution and the function of $\mathrm{PHC}$ are aspects to be considered in the care of this population group. However, despite the expectations mentioned above, the changes in the NPCP threaten this achievement, given that the review of the new policy text indicates a relativization of the coverage, as it does not commit to the adoption of parameters to favor a more qualified process of progressive attention. ${ }^{25}$

In Brazil, the landmark of public health policies focused on LGBTI+ population is the 1980s, based on the AIDS epidemic that facilitated the fights in defense of sexual rights, with the inclusion of this population as a risk group vulnerable to STIs and AIDS, and with further advances towards health care with a view to integral care. ${ }^{9}$

Given this care, the Brazilian PHC structure comprises the work of a multidisciplinary team within a Basic Health Unit (BHU). Among the various compositions that a $\mathrm{PHC}$ working team can have, the Family Health team (FHt) stands out, which is the priority strategy of the organization of the Brazilian $\mathrm{PHC}$ teams. The $\mathrm{FHt}$ is made up of a doctor and a nurse (preferably experts in Family Health), a nursing assistant and/or technician, community health agents, being able to join this composition, endemic disease combating agents and oral health professionals. ${ }^{26}$

The work of a nurse in the PHC as a Family Health team member implies the performance of functions based on the principles of the SUS that, as a matter of principle, does not allow exclusions of any kind and has the duty to promote equality. In the meantime, according to the NPCP, the nurse is responsible for performing and supervising the reception, as well as for executing risk stratification, at any stage of the individual's life cycle, very often being the first professional with a bachelor's degree that the user has contact with when they seek for health care at a Basic Health Unit.

In the PHC context, besides the program's demands that compose the booked consultations, work is also done with the spontaneous demand that may be one related to an acute health condition or to a complaint that the user considers important at that moment. In both types of demands, the nurse is able to act 
autonomously, with resolution and completion of care, or can refer the user to another professional.

Regarding nursing, two important activity fields stand out: nursing consultation and the development of educational groups, be them in the BHU as well as in other spaces available in the territory, such as churches, schools, and neighborhood associations. Nevertheless, within the scope of nursing consultation in the Family Health Strategy, studies are very limited to lines of care such as hypertension, diabetes, women (heterosexual) and children health, although there are a few studies about the LGBTI+ population. ${ }^{27,28}$ Despite the report of the specificities, social determinants of health and inequities, debating the nursing care for the LGBTI+ population within the Brazilian PHC is important in the set of actions that aim to give visibility and legitimize the space of this professional in welcoming and caring for the LGBTI+ population.

In this context, PHC is characterized as a fundamental tool for the education process and the dissemination of qualified information that assist in the process of awareness of the population. Nurses can occupy a prominent place in this investment, by means of education in health in educational groups in the community and within the schools, approaching among many themes such as the culture of peace and human rights.

But it is necessary to consider that, to be effective, professional performance needs to overcome challenges and barriers that prohibit care. In relation to the health care professionals, studies show that one in five LGBTI+ individuals does not reveal their sexual orientation to the health care practitioner during the consultation, transsexual people tend to avoid seeking health care even when ill and there are even reported cases of denial of consultation to the LGBTI+ group, all of which a result of the fear of discrimination by the health care practitioners and services. ${ }^{29}$

A study conducted with 14 basic health unit doctors from a capital in the Brazilian Northeast Region revealed that none of them received training to deal with the health of the LGBTI+ population and that the Curriculum Guidelines of the Medical School do not consider the most expressive aspects of this population group's health. ${ }^{30}$ In a review study on the nursing care for the trans population 11 publications were found in the 2005-2001 period, most from abroad, with only one Brazilian publication. ${ }^{31}$ The results show that few nurses feel able to serve this population and that there is lack of knowledge and competency for the interaction with trans people and for dealing with gender diversity in the professional practice; thus, it is necessary to increase or to include contents in the nursing curricula. ${ }^{31}$

Corroborating with this data, a study with 19 students from a federal university in the Brazilian South Region evidenced weaknesses in their knowledge, both about their concepts of homo and bisexuality as well as about the training on the care for this group, with a superficial approach in classrooms, leading them to search for extracurricular activities ${ }^{32}$ Homo and bisexual women have fewer chances of being offered to undergo a cytopathological cervical examination and are exposed to acts of violence during the procedure, such as the use of a speculum of an inadequate size and without the necessary lubrication. ${ }^{33}$

To assess the knowledge, attitudes, and cultural competency of undergraduate nursing students in serving the LGBTI+ population, researchers performed an educational intervention and applied an Attitude Scale Concerning Lesbian and Gay Men before and after the intervention. The results evidenced a statistically significant increase in the students' positive attitudes and knowledge level and showed that the inclusion of the contents about health care for the LGBTI+ population in the curricula contributes to the promotion of the students' cultural competency and sensibility to the subject. ${ }^{34}$

In receiving health care by the nurse, the implementation of the Nursing Process implies a careful collection of the individual's history so that the Nursing Diagnosis and the Care Plan are well instructed, taking into account the user's specificities. Regarding the care actions, their practice requires an understanding of the social context, identification of the health needs and the expectations of the people are under the nurse's professional care. ${ }^{35}$ Therefore, it's necessary that the professional is well trained for an open and enlarged approach of the individuals who seek care.

The specific needs and the challenges faced by the LGBTI+ population require preparation and lack of training can perpetuate prejudice and discrimination, resulting in poor quality health care actions and in an increased incidence of diseases and their risk factors; therefore, there must be investments in professional education and practice guidelines, so that there is a wide, comprehensive, scientific, and human offer to this population group. ${ }^{6}$ About the clinical guidelines for the provision of primary care and family planning services to the LGBTI+ population, a review study shows that there are important advances. ${ }^{36}$

In this sense, there is the need to reflect on this matter and to place it on the debate agenda, both in the training as well as in the permanent education activities in health care services, and also in the scientific events of the area, facilitating to consider the specificity of the health context and the lives of the LGBTI+ people, expanding dialog and sharing the knowledge needed for the health care practices to be incorporated in the PHC daily routine.

The data and the discussion contained in this study lead to reflect that thinking and practicing the care for the LGBTI+ population professionally necessarily implies considering their existence and expression, knowing their specific needs and the proper approaches in the professional training. Considering human plurality in its varied possibilities of expression is the primary condition for the practice of health care, despite the complexity inherent to these fields: health, nursing, care. 


\section{CONCLUSION}

Despite existing, resisting, and occupying the spaces of society, the LGBTI+ population finds itself invisible in the implementation of public policies. As biological bodies and immersed in multiple social contexts, they need attention that involves health in its broadest concept. Although the LGBT National Health Policy exists for seven years and one of its objectives is to identify the health needs of the mentioned population, we are facing the necessity to expand studies, especially in Nursing, which outline the profile of this population group in respect not only to the field of bio-clinical needs, but also to defining the sociodemographic profile of this population and the social determination of their health.

The LGBTI+ community as a whole has particularities, but each population group that composes it has specificities that differentiate them from each other. There are differences in gender identity, gender expression, sexual orientation, and biological sex. Nursing, science and art of caring for human beings in all vital cycles and life contexts that in Brazil occupies half of the jobs in health care services, have as primary function to establish a helping relationship for all who are under their care responsibility. The LGBTI+ population, as a group of citizens using the SUS, is also under the responsibility of Nursing in the scope of Primary Health Care and, thus, it is this professional category's responsibility to provide integral assistance aiming to minimize the inequalities suffered by this population.

Nursing professionals must assume the expressed responsibility, in principle and in nature, not only in the political dimension, but also in the ethical and legal dimensions of care, calling on educational institutions and scientific associations, to promote a debate over technical, scientific, cultural, and political developments in favor of sexual and gender minorities.

\section{FINANCIAL SUPPORT}

Carlos Chagas Filho Foundation for Reseach Support of the State of Rio de Janeiro (Fundação Carlos Chagas Filho de Amparo à Pesquisa do Estado do Rio de Janeiro, FAPERJ) Bolsa Nota 10 scholarhip program (Doctorate), process number E-26/200.557/2018, PhD scholarship granted to Rodrigo Nogueira da Silva. National Council of Science and Technology (Conselho Nacional de Ciência e Tecnologia, CNPq), Research Productivity Scholarship granted to Márcia de Assunção Ferreira.

\section{REFERENCES}

1. Reis T. Manual de Comunicação LGBTI+ [Internet]. Curitiba: Aliança Nacional LGBTI, GayLatino; 2018; [cited 2019 jul 17]. Available from: http://www.grupodignidade.org.br/wp-content/uploads/2018/05/ manual-comunicacao-LGBTI.pdf

2. Ramos JGG, Esquivel CLW. The right to health as a fundamental human right: brief observations regarding its legal form to effective social. Ciências Sociais Apl em Rev - UNIOESTE/MCR [Internet]. 2015; [cited 2019 jul 17]; 15(28):9-40. Available from: http://e-revista.unioeste.br/ index.php/csaemrevista/article/view/15308/10385
3. Reis T, Eggert E. Ideologia de gênero: uma falácia construída sobre os planos de educação brasileiros. Educ Soc [Internet]. 2017 jan; [cited 2019 jul 17]; 38(138):9-26. Available from: http://dx.doi.org/10.1590/ es0101-73302017165522

4. Ferreira BO, Pedrosa JIS, Nascimento EF. Gender diversity and access to the Unified Health System. Rev Bras Promoç Saúde [Internet]. 2018 jan/mar; [cited 2019 jul 17]; 31(1):1-10. Available from: http://dx.doi. org/10.5020/18061230.2018.6726

5. Ministério da Saúde (BR). Secretaria de Gestão Estratégica e Participativa. Departamento de Apoio à Gestão Participativa. Política Nacional de Saúde Integral de Lésbicas, Gays, Bissexuais, Travestis e Transexuais [Internet]. Brasília (DF): Ministério da Saúde;2013. Available from: http://bvsms.saude.gov.br/bvs/publicacoes/politica_nacional_ saude_lesbicas_gays.pdf

6. Hafeez H, Zeshan M, Tahir MA, Jahan N, Naveed S. Health Care Disparities Among Lesbian, Gay, Bisexual, and Transgender Youth: A Literature Review. Cureus [Internet]. 2017 apr; [cited 2019 jul 17]; 9(4):e1184. Available from: http://dx.doi.org/10.7759/cureus.1184

7. Santos AR, Santos RMM, Souza ML, Boery RNSO, Sena ELS, Yarid SD. Implicações bioéticas no atendimento de saúde ao público LGBTT. Rev Bioét [Internet]. 2015 aug; [cited 2019 jul 17]; 23(2):400-8. Available from: $h$ ttp://dx.doi.org/10.1590/1983-80422015232078

8. Albuquerque GA, Garcia CL, Quirino GS, Alves MJH, Belém JM, Figueiredo FWS, et al. Access to health services by lesbian, gay, bisexual, and transgender persons: systematic literature review. BMC Int Health Hum Rights [Internet]. 2016 jan; [cited 2019 jul 17]; 16(2):1-10. Available from: http://dx.doi.org/10.1186/s12914-015-0072-9

9. Prado EAJ, Sousa MF. Políticas Públicas e a saúde da população LGBT: uma revisão integrativa. Tempus, Actas de Saúde Colet [Internet]. 2017 nov; [cited 2019 jul 17]; 11(1):69. Available from: http://dx.doi. org/10.18569/tempus.v11i1.1895

10. Pelullo CP, Di Giuseppe G, Angelillo IF. Frequency of Discrimination, Harassment, and Violence in Lesbian, Gay Men, and Bisexual in Italy. PLoS One [Internet]. 2013 aug; [cited 2019 jul 17]; 8(8):e74446. Available from: http://dx.doi.org/10.1371/journal.pone.0074446

11. Solazzo A, Brown TN, Gorman BK. State-level climate, anti-discrimination law, and sexual minority health status: An ecological study. Soc Sc Med [Internet]. 2018 jan; [cited 2019 jul 17]; 196:158-65. Available from: http://dx.doi.org/10.1016/j.socscimed.2017.11.033

12. Silva RN, Freitas FDS, Araújo FP, Ferreira MA. A policy analysis of teamwork as a proposal for healthcare humanization: implications for nursing. Int Nurs Rev [Internet]. 2016 nov; [cited 2019 jul 17]; 63(4):572-9. Available from: $h$ ttp://dx.doi.org/10.1111/inr.12331

13. Souza DC, Coelho IM, Martins FS, Honorato EJS. Assassinatos de LGBTs no Brasil - uma análise de literatura entre 2010-2017. Periódicus [Internet].2019 apr; [cited 2019 jul 17]; 1(10):24-39. Available from: http:// dx.doi.org/10.9771/peri.v1i10.27919

14. Transgender Europe. TVT TMM Update - Trans Day of Remembrance (TDoR) 2018: Press Release [Internet]. Berlin: Transrespect; 2018. Available from: https://transrespect.org/wp-content/uploads/2018/11/ TVT_TMM_TDoR2018_PR_EN.pdf

15. Grupo Gay da Bahia (GGB). Mortes violentas de LGBT+ no Brasil: relatório 2018 [Internet]. Rio de Janeiro: GGB; 2019. Available from: https://homofobiamata.files.wordpress.com/2019/01/relatorio-2018-1. pdf

16. Associação Nacional de Travestis e Transexuais do Brasil (ANTRA). Instituto Brasileiro Trans de Educação (IBTE). Dossiê assassinatos e violência contra travestis e transexuais no Brasil em 2018 [Internet] Brasil: ANTRA;2019. Available from: https://antrabrasil.files.wordpress. com/2019/01/dossie-dos-assassinatos-e-violencia-contra-pessoastrans-em-2018.pdf

17. Silva LKM, Silva ALMA, Coelho AA, Martiniano CS. Uso do nome social no Sistema Único de Saúde: elementos para o debate sobre a assistência prestada a travestis e transexuais. Physis [Internet] 2017 jul; [cited 2019 jul 17]; 27(3):835-46. Available from: http://dx.doi. org/10.1590/s0103-73312017000300023 
18. Rocon PC, Sodré F, Zamboni J, Rodrigues A, Roseiro MCFB. O que esperam pessoas trans do Sistema Único de Saúde? Interface (Botucatu) [Internet]. 2018 mar; [cited 2019 jul 17]; 22(64):43-53. Available from: $\mathrm{http}: / / \mathrm{dx}$.doi.org/10.1590/1807-57622016.0712

19. Silva ALR, Finkle M, Moretti-Pires RO. Representações sociais de trabalhadores da Atenção Básica à Saúde sobre pessoas LGBT. Trab Educ Saúde [Internet]. 2019 feb; [cited 2019 jul 17]; 17(2):e0019730. Available from: http://dx.doi.org/10.1590/1981-7746-sol00197

20. Batista $\mathrm{MCH}$, Zambenedetti G. Uma pesquisa-intervenção sobre prevenção às IST/HIV com mulheres lésbicas e bissexuais. Rev Psicol em Pesqui [Internet]. 2017 dec; [cited 2019 jul 17]; 11(2):42-50. Available from: http://dx.doi.org/10.24879/2017001100200180

21. Bostwick WB, Boyd CJ, Hughes TL, West BT, McCabe SE. Discrimination and mental health among lesbian, gay, and bisexual adults in the United States. Am J Orthopsychiatry [Internet]. 2014; [cited 2019 jul 17]; 84(1):35-45. Available from: http://dx.doi.org/10.1037/h0098851

22. Guimarães AN, Marqui GDS, Brum MLB, Vendruscolo C, Werner JM, Zanatta EA. Narratives of young people on same-sex relationships about their path and implications for mental health. Esc Anna Nery [Internet]. 2019 jan; [cited 2019 jul 17]; 23(1):e20180240. Available from: http://dx.doi.org/10.1590/2177-9465-ean-2018-0240

23. Ministério da Saúde (BR). Secretaria de Vigilância em Saúde. Secretaria de Atenção à Saúde. Política Nacional de Promoção da Saúde (PNaPS): Revisão da Portaria MS/GM no 687, de 30 de março de 2006 [Internet]. Brasília (DF): Ministério da Saúde; 2014. Available from: http://bvsms.saude.gov.br/bvs/publicacoes/politica_nacional_ promocao_saude_pnaps.pdf

24. Almeida ER, Sousa ANA, Brandão CC, Carvalho FFB, Tavares G, Silva KC. National primary health care policy in Brazil: an analysis of the review process (2015-2017). Rev Panam Salud Pública [Internet] 2018 oct; [cited 2019 jul 17]; 42:e180. Available from: http://dx.doi. org/10.26633/RPSP.2018.180

25. Morosini MVGC, Fonseca AF, Lima LD. Política Nacional de Atenção Básica 2017: retrocessos e riscos para o Sistema Único de Saúde. Saúde Debate [Internet]. 2018 jan; [cited 2019 jul 17]; 42(116):11-24. Available from: http://dx.doi.org/10.1590/0103-1104201811601

26. Ministério da Saúde (BR). Portaria n. 2.436, de 21 de setembro de 2017. Aprova a Política Nacional de Atenção Básica, estabelecendo a revisão de diretrizes para a organização da Atenção Básica, no âmbito do Sistema Único de Saúde (SUS) [Internet]. Brasília (DF): Ministério da Saúde;2017. Available from: http://bvsms.saude.gov.br/bvs/saudelegis/ gm/2017/prt2436_22_09_2017.html

27. Crispim JEB, Barreto EF, Nogueira WBAG, Almeida SA. Assistência de enfermagem à mulher lésbica e bissexual na atenção básica: protocolo de atendimento. Rev Pesqui Cuid Fundam [Internet]. 2018; [cited 2019 jul 17]; 10(3):34-9. Available from: http://www.seer.unirio.br/index.php/ cuidadofundamental/article/viewFile/7599/6584
28. Sousa P, Abrão FMS, Costa AM, Ferreira LOC. Humanization on the embracement of lesbians, gays, bisexuals, transvestites and transsexuals in primary care: bioethical thoughts for nursing. Rev Enferm UFPE on line [Internet]. 2011 jun; [cited 2019 jul 17] 5(4):1064-71. Available from: http://dx.doi.org/10.5205/1981-8963v5i4a6755p1064-1071-2011

29. National Alliance on Mental IIIness (NAMI). LGBTQ [Internet]. Arlington: NAMI; 2016. Available from: https://www.nami.org/Find-Support/ LGBTQ

30. Negreiros FRN, Ferreira BO, Freitas DN, Pedrosa JIS, Nascimento EF. Saúde de Lésbicas, Gays, Bissexuais, Travestis e Transexuais: da Formação Médica à Atuação Profissional. Rev Bras Educ Med [Internet]. 2019 mar; [cited 2019 jul 17]; 43(1):23-31. Available from: http://dx.doi.org/10.1590/1981-52712015v43n1rb20180075

31. Rosa DF, Carvalho MVF, Pereira NR, Rocha NT, Neves VR, Rosa AS. Nursing Care for the transgender population: genders from the perspective of professional practice. Rev Bras Enferm [Internet]. 2019 feb; [citado 2019 jul 17]; 72(Suppl 1):299-306. Available from: http:// dx.doi.org/10.1590/0034-7167-2017-0644

32. Nietsche EA, Tassinari TT, Ramos TK, Beltrame G, Salbego C Cassenote LG. Nursing training for care to the homosexual and bisexual population: students' perception. Rev Baiana Enferm' [Internet]. 2018 jul; [cited 2019 jul 17]; 32:e25174. Available from: http://dx.doi. org/10.18471/rbe.v32.25174

33. McCune K, Imborek K. Clinical Care of Lesbian and Bisexual Women for the Obstetrician Gynecologist. Clin Obstet Gynecol [Internet]. 2018 dec; [cited 2019 jul 17]; 61(4):663-73. Available from: http://dx.doi. org/10.1097/GRF.0000000000000399

34. Strong KL, Folse VN. Assessing Undergraduate Nursing Students Knowledge, Attitudes, and Cultural Competence in Caring for Lesbian, Gay, Bisexual, and Transgender Patients. J Nurs Educ [Internet]. 2015 jan; [cited 2019 jul 17]; 54(1):45-9. Available from: http://dx.doi. org/10.3928/01484834-20141224-07

35. Zoboli ELCP, Schveitzer MC. Nursing values as social practice: a qualitative meta-synthesis. Rev Latino-Am Enfermagem [Internet]. 2013 jun; [cited 2019 jul 17]; 21(3):695-703. Available from: http://dx.doi. org/10.1590/S0104-11692013000300007

36. Klein DA, Malcolm NM, Berry-Bibee EN, Paradise SL, Coulter JS, Baker KK, et al. Quality Primary Care and Family Planning Services for LGBT Clients: A Comprehensive Review of Clinical Guidelines. LGBT Health [Internet]. 2018 apr; [cited 2019 jul 17]; 5(3):153-70. Available from: http://dx.doi.org/10.1089/lgbt.2017.0213 